\title{
Nej, det er ikke bare løgn
}

Sille Obelitz Søe, PhD, Postdoc i informationsfilosofi, Institut for Informationsstudier, Københavns Universitet

Begreber som 'Fake News', misinformation og disinformation har fyldt en del $i$ den politiske offentlighed $i$ den seneste tid. Der er til stadighed en vis uklarhed omkring, hvad disse begreber doekker over, men én ting er sikkert: 'Fake News' er falske og de skal bremses så sandheden kan vinde frem. Eller ...? Problemet er nemlig, at det i bund og grund ikke er et spørgsmål om sandhed og falskhed, men i stedet er et spørgsmål om vildledning og ikke-vildledning.

\section{Introduktion}

'Fake News', alternative fakta, det postfaktuelle samfund. Vildledning, snyd og bedrag fylder mere og mere i nyhedsbilledet. Både i form af decideret falske nyhedshistorier der finder vej gennem etablerede nyhedskanaler og sociale medieplatforme, samt i form af artikler om fænomenerne selv. Et fællestræk for debatten vedrørende falske nyheder, alternative fakta og det postfaktuelle er et fokus på, hvad der er sandt, og hvad der er falsk. Det sande er en god ting, som politikere og meningsdannere gerne vil have spredt ud til befolkningen. Det falske er noget skidt, der skal begrænses, bekæmpes og fjernes. Bag ved denne logik ligger frygten. Frygten for hvilke konsekvenser 'Fake News' og anden vildledning har for demokratiet - det oplyste beslutningsgrundlag. Det er spørgsmålet om, hvad et samfund stiller op, hvis alle dets borgere vildledes af falske nyheder spredt via sociale medieplatforme.

Selvom begreberne misinformation og disinformation - både i sig selv og under diverse synonymer - $\mathrm{i}$ den seneste tid er kommet $\mathrm{i}$ fokus $\mathrm{i}$ journalistikken, $\mathrm{i}$ samfundsdebatten, i private hjem, såvel som i forskningsregi, så er der stadig en vis uklarhed omkring, hvad de egentlig dækker over. Misinformation og disinformation er dog ikke nye begreber og de bagvedliggende fænomener og mekanismer er heller ikke nye. Hvad der er nyt, er derimod måden hvorpå misinformation og disinformation spredes i vores samfund, både lokalt og globalt. Sociale medieplatforme såsom Facebook og Twitter har muliggjort den øgede hastighed hvormed rygter, artikler og billeder etc. spredes. Samtidig er rækkevidden og antallet af modtagere også øget markant (jf. Hjøllund 2017). 
Til trods for at problemet i medierne ofte er omtalt som en udfordring i forhold til sikring af fakta og sandhed, kan problemet bedre karakteriseres som en udfordring i forhold til at værne mod tilsigtet og utilsigtet vildledning. At det først og fremmest handler om vildledning og ikke om sandhed over for falskhed er den helt centrale pointe. Vildledning er et komplekst fænomen og dets relation til kategorierne sandt og falsk er ikke så simpel, som det ofte ser ud. Med andre ord, hvis vi bliver ved med udelukkende at fokusere på at skelne sandt fra falsk - løgn fra sandhed, fiktion fra fakta - så overser vi væsentlige former for vildledning, hvor sandhedsværdien (dvs. relationen til enten 'sandt' eller 'falsk') ikke er entydig, eller måske slet ikke kan afgøres. Med et ensidigt fokus på sandt-falsk bliver det også uklart, hvordan vi skal forholde os til satire og ironi, der netop fungerer via deres blanding af fakta og fiktion.

Centralt for denne artikel står en teoretisk afklaring af begreberne information, misinformation og disinformation og deres indbyrdes relationer. Denne afklaring tager sit udgangspunkt $\mathrm{i}$ begreberne løgn, vildledning og bedrag, da disse begreber har fået en hovedrolle i retorikken omkring 'Fake News'. Det er med afsæt i litteraturen om løgn, vildledning og bedrag, at disinformation diskuteres og analyseres. Udgangspunktet for disinformation viser sig at være afgørende for, hvordan vi kan forstå begrebet information, derfor kommer analyserne og diskussionerne af disinformation før analyserne og diskussionerne af information. Herefter analyseres og diskuteres begrebet misinformation som et begreb, hvor sigtet er information, men udfaldet er vildledning. Det samlede mål er et argument for, hvorfor kategorierne sandt og falsk kommer til kort over for vildledning. Med andre ord er argument, at det først og fremmest handler om at skelne mellem vildledning og ikke-vildledning, når misinformation og disinformation skal identificeres - og ikke som hidtil et ensidigt fokus på at skelne mellem sandt og falsk. Dette argument tjener både som forskningsbidrag til informationsfilosofien samt som formidlende indspark i forhold til andre fagfelter, der beskæftiger sig med begreberne misinformation og disinformation. For at sikre den demokratiske debat er det væsentligt at kunne skelne mellem information, misinformation og disinformation og således prøve at gennemskue, hvornår man forsøges vildledt. En teoretisk afklaring af begreberne information, misinformation og disinformation, samt fænomenet vildledning mere generelt, er nødvendig for at kunne opbygge evnen til at identificere disse fænomener, når de spiller sig ud i den offentlige debat, på sociale medieplatforme, i journalistikken eller i al almindelighed.

\section{Teoretiske perspektiver}

Misinformation og disinformation er begge former for vildledning. Ofte, både i den filosofiske litteratur (fx Dretske 1981, 2008; Floridi 2005a, 2005b, 2011) og i journalistikken (jf. Wardle 2016) diskuteres de som modpoler til information - gerne med en skelnen mellem information som værende sandt og misinformation og disinformation som værende falsk. Det dominerende fokus på vildledning som værende falsk og den 
dertil hørende forkastelighed fordrer en lyst og en trang til at udrydde og eliminere misinformation og disinformation - især på de sociale medier. Således har flere forskningsprojekter forsøgt at udvikle værktøjer, der automatisk kan identificere misinformation og disinformation på fx Facebook og Twitter. Som eksempler kan nævnes PHEMEprojektet (2014), Kumar og Geethakumari's (2014) Twitter-algoritme og den nyligt lancerede platform Hoaxy (Shao et al. 2016). Fælles for disse projekter er ønsket om automatisk (algoritmisk) detektering af misinformation og disinformation - dvs. identificering af det, der er falsk - med henblik på at hjælpe den enkelte til at træffe bedre beslutninger. Den underforståede logik er, at hvis misinformationen og disinformationen identificeres, så kan den markeres, hvormed det bliver synligt for den enkelte, at der her er tale om vildledning. Dermed kan vildledning undgås og uden vildledning træffes der bedre beslutninger.

Problemet er blot, at begreberne misinformation og disinformation, samt fænomenet vildledning generelt, er mere nuancerede end som så. Skellet mellem information på den ene side og misinformation og disinformation på den anden side er ikke blot et skel mellem noget, der er sandt og noget, der er falsk. Vildledning som fænomen er yderst komplekst og kommer i mange grader og varianter. Det samme gælder i øvrigt begrebet information. Hvad information egentlig er for en størrelse, har været udgangspunktet for mange diskussioner i både informationsstudier og informationsfilosofi (fx Adriaans 2012; Budd 2011; Dretske 1981; Floridi 2005a; Fox 1983; Furner 2004; Mai 2013; Robinson \& Bawden 2014; Scarantino \& Piccinini 2010).

For at få et større indblik $\mathrm{i}$ begreberne misinformation og disinformation samt fænomenet vildledning mere generelt, må vi ty til den filosofiske litteratur vedrørende løgn, vildledning og bedrag (fx Adler 1997; Fallis 2010; Mahon 2008).

\section{Løgn og bedrag}

I litteraturen om vildledning ligger fokus ofte på definitioner af og distinktioner mellem de tre begreber 'løgn', 'vildledning' og 'bedrag'. Dette kan synes forvirrende da løgn er en specifik variant af vildledning (én blandt mange) og bedrag er et aspekt ved vildledning når denne virker. Eftersom misinformation og disinformation først er begyndt at vinde indpas som selvstændige analytiske begreber inden for de seneste 10-20 år ${ }^{1}$, er det dog ikke så underligt med et fokus på forskellene mellem vildledning, løgn og bedrag. Rationalet er at analysere vildledning generelt, at analysere prototypen på den intentionelle vildledning (løgnen) samt at analysere hvad der skal til for, at vildledningen kan siges at virke (bedraget). Det diskuteres til stadighed, hvorledes disse begreber skal defineres (jf. Mahon 2008). Diskussionerne tager dog udgangspunkt i nogle klassiske standarddefinitioner, der giver et fint indtryk af, hvad løgn, vildledning og bedrag er for

\footnotetext{
${ }^{1}$ Hermed ikke sagt, at begreberne misinformation og disinformation først er opstået inden for de sidste 10-20 år. De er oftest blot blevet behandlet som restkategorier til information i stedet for som selvstændige analytiske kategorier.
} 
begreber.

At lyve er "to make a believed-false statement to another person with the intention that the other person believe that statement to be true." (Mahon 2008, afsnit 1). Løgnen er intentionel, den er bevidst, og det er dermed ikke muligt at lyve uden at vide det. Dermed ikke sagt, at det ikke er muligt at komme til at sige noget falsk til nogen, som så tror, at det er sandt. Dette er selvfølgelig muligt, men så er der ikke længere tale om løgn men 'blot' tale om vildledning: "deception, like lying, is intentional. (...) [the] term "mislead" [is used] to cover cases of causing false beliefs either intentionally or unintentionally (...)." (Mahon 2008, afsnit 3). Dermed er vildledning et bredere begreb end løgnen, da vildledning dækker både den intentionelle og den ikke-intentionelle vildledning.

Hertil kommer begrebet bedrag, der ligesom løgnen, er intentionelt. 'At bedrage' er "to intentionally cause [someone] to have a false belief that is known or believed to be false." (Mahon 2008, afsnit 3). Forskellen mellem løgnen og bedraget er, at bedrag er et success-begreb. Det betyder, at der kun er tale om bedrag såfremt nogen rent faktisk vildledes og oprigtigt tror på vildledningen. Det er dette forhold, der ligger implicit i definitionen qua ordet 'cause'. Løgn er ikke et success-begreb. Det er dermed muligt at lyve desuagtet om nogen føres bag lyset eller ej. Vildledning i sig selv er heller ikke et success-begreb. Det er dermed også muligt at vildlede, uden at nogen bliver vildledt. Såfremt løgnen og den intentionelle vildledning virker og nogen vildledes, så er det muligt at tale om bedrag (Mahon 2008). På denne måde er bedrag et aspekt, eller en egenskab, ved intentionel vildledning, der ikke nødvendigvis opnås. Hertil skal det pointeres at såfremt vildledningen er ikke-intenderet, så kan der aldrig blive tale om bedrag, heller ikke selvom nogen faktisk vildledes. Dette skyldes at definitionen af bedrag inkluderer intentionalitet - dvs. bedraget skal være intentionelt for at være bedrag.

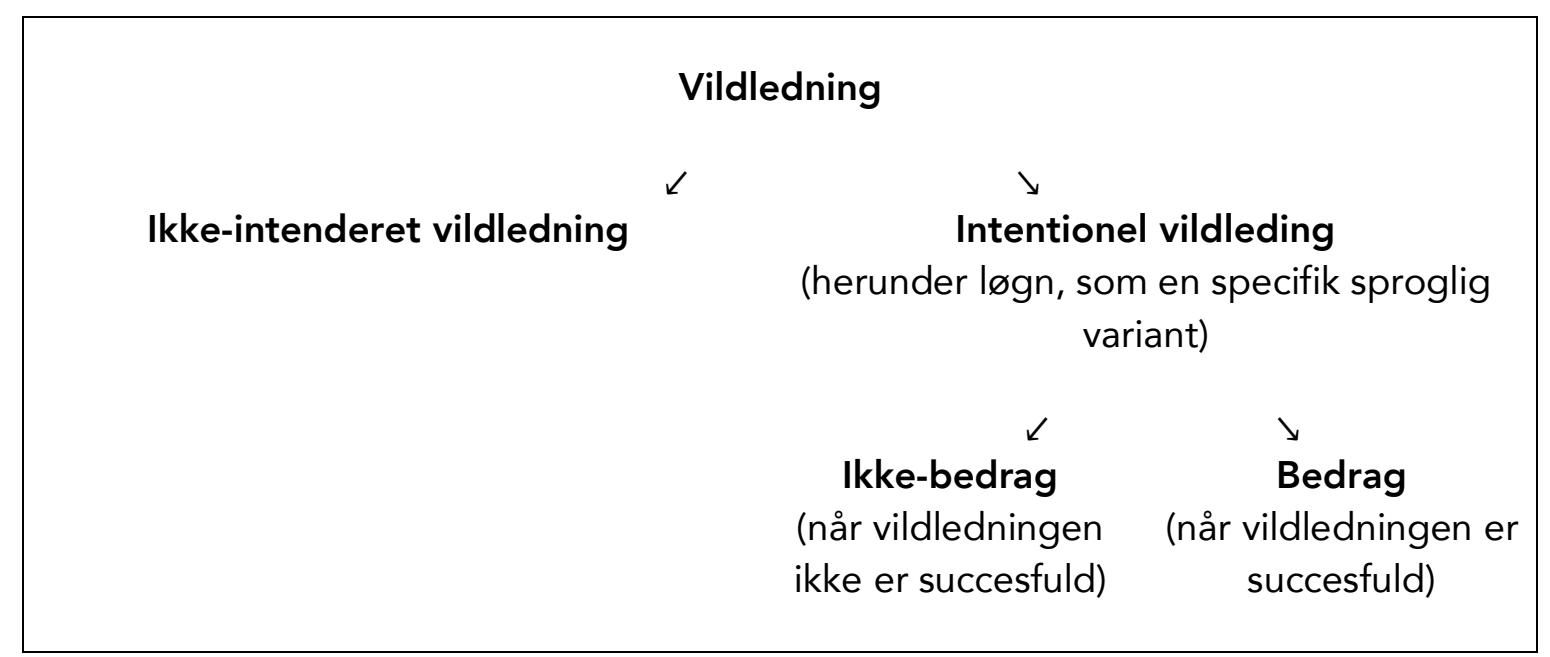

Fig. 2.1: Vildledning, løgn og bedrag. 


\section{Disinformation}

Hvor vildledning, løgn og bedrag diskuteres som selvstændige analytiske begreber $\mathrm{i}$ forhold til hinanden, har de informationsfilosofiske diskussioner af misinformation og disinformation for det meste deres udspring i diskussioner af, hvad information er ( $\mathrm{fx}$ Dretske 1981; Floridi 2005a, 2005b, 2011; Fox 1983). Det vil sige at misinformation og disinformation oftest diskuteres (eller blot nævnes) som restkategorier til information som det, der er tilbage når information er blevet defineret; det, information ikke er. En undtagelse - og dermed et godt sted at starte - er enkelte konceptuelle analyser af disinformation, der ikke udspringer af diskussioner af informationsbegrebet, men i stedet udspringer af litteraturen vedrørende løgn, vildledning og bedrag (Fallis 2014, 2015). Målet for disse analyser er at give en redegørelse for og samlet fremstilling af alle de forskellige varianter af disinformation, som vi intuitivt kan tænke os til (fx løgn) - samtidig med at satire, ironi og utilsigtede fejl ikke dækkes ind under definitionen af disinformation (Fallis 2014, 2015).

Disinformation er den information, der har til funktion at vildlede (Fallis 2015) med andre ord, den information hvor det ikke er en fejl, at den er vildledende. Der er to måder, hvormed noget kan tilegne sig en funktion - enten via evolutionær udvikling eller via design (Fallis 2015). Begge former for funktion gør sig gældende i forbindelse med disinformation. Adaptiv disinformation - den form for vildledning man taler om hos dyr - fungerer via den evolutionært udviklede funktion. Vildledningen er udviklet og tilpasset over tid, fordi den gavner det dyr, der vildleder. Dyret kan ikke siges at have en intention om at vildlede, men samtidig er det ikke en fejl, at det vildleder, da det gentagende gange får noget ud af at gøre det - fx mere mad. Udviklingen kan også ske over længere tid, således at det ikke er det enkelte dyr, der gentagende gange har gavn af vildledningen, men derimod arten som sådan der gavnes, fordi de enkelte eksemplarer ved hjælp af vildledningen undgår at blive spist af rovdyr (Fallis 2015; Skyrms 2010). Adaptiv disinformation er interessant i en politisk kontekst, da der er noget, der tyder på at de første tilfælde af fabrikerede historier med betegnelsen 'Fake News' (dvs. startskuddet på 'Fake News' fænomenet) blev produceret og delt med en intention om at tjene penge. Vildledningen som sådan var ikke intenderet, men den var dog heller ikke en fejl - den gavnede producenterne, der begyndte at tjene mange penge på deres fabrikerede historier. Historier der gradvist tilpassede sig forholdene for størst mulig gevinst - dvs. benyttede mekanismerne bag adaptiv disinformation (Fallis 2017).

I de fleste andre former for disinformation er vildledningsfunktionen designet, således at vildledningen er intentionel - vildledningsfunktionen er udviklet forsætligt. Det er vigtigt her at bemærke forskellen på intention og intentionalitet. Groft sagt er en intention et ønske om, at en bestemt handling udføres med en bestemt ønsket konsekvens. Intentionalitet er blot en rettethed i handlingen - den er rettet mod noget - eller en forudseenhed om handlingens (mulige) konsekvenser, uden at disse konsekvenser nødvendigvis er intenderede. En intenderet handling vil dermed altid være intentionel, hvorimod en intentionel handling ikke nødvendigvis er intenderet (men den kan være 
det). Det er dermed afgørende, at disinformation er defineret med henvisning til intentionalitet og funktion. Eksempler på disinformation er visuel disinformation (fx manipulerede eller forfalskede billeder, grafer og kort), side-effect disinformation (tilfælde hvor vildledningen ikke er direkte intenderet, men er forudsigelig og dermed ikke tilfældig ${ }^{2}$ ) og sand disinformation.

Sand disinformation er den mest kontroversielle form for disinformation i den forstand, at den gængse forståelse af disinformation er, at begrebet er defineret ved falskhed (jf. Dretske 1981; Floridi 2011; Wardle 2016; PHEME 2014; Kumar \& Geethakumari 2014; Shao et al. 2016). Kravet om falskhed, som det der definerer disinformation og misinformation, skyldes at disse to begreber behandles som restkategorier til information - dvs. det der er tilbage, når information er defineret - $\mathrm{i}$ de informationsfilosofiske diskussioner, der tager deres udspring i informationsbegrebet. Her opereres som oftest med en dikotomi mellem semantisk information som værende karakteriseret ved sandhed og misinformation og disinformation som værende karakteriseret ved falskhed. Det er ofte også denne dikotomi der opereres med i journalistikken og de forskellige identifikationsprojekter. Således defineres disinformation, i informationsfilosofien, som "misinformation purposefully conveyed to mislead the receiver into believing that it is information" (Floridi 2011, 260), hvor falskheden introduceres implicit via 'misinformation', der defineres som 'velformet, meningsfuld data, der er falsk' (Floridi 2005a, 2011). Udgangspunktet er med andre ord et sandfærdigt informationsbegreb og så må restkategorierne misinformation og disinformation nødvendigvis være alt det falske. I denne sand-falsk dikotomi er sand disinformation en umulighed - en selvmodsigelse. Det er lige præcis her, at analysernes begreb-fokus og teoretiske udspring er af højeste betydning. Sand disinformation, som en særlig variant, er ikke udviklet som en restkategori til information. Sand disinformation (Fallis 2014, 2015) er udviklet på baggrund af de konceptuelle analyser af disinformation, der tager deres udspring i litteraturen om løgn, vildledning og bedrag (fx Adler 1997; Fallis 2010; Mahon 2008). I denne litteratur er det alment anerkendt at såkaldte implikaturer - især i den specifikke form kaldet falske implikaturer - er et effektivt vildledningsredskab, der adskiller sig fra den almindelige løgn. Det er bl.a. disse implikaturer, der gør sand disinformation mulig (en anden mekanisme er intentionelle udeladelser, jf. nedenfor) - en mulighed der sætter spørgsmålstegn ved sandt-falsk-dikotomien og dermed rationalet for de projekter, der forsøger at identificere misinformation og disinformation automatisk. 'Implikatur' er et sprogfilosofisk begreb hentet hos dagligsprogsfilosoffen Paul Grice (1967). 'Implikaturen' er en mekanisme i sproget (både verbalt og non-verbalt), der opstår fordi menneskelige agenter ofte mener noget andet eller noget mere med det, de ytrer end den bog-

\footnotetext{
2 Et eksempel på side-effect disinformation er forsøg hvor forskere har indsat fejlagtig information på Wikipedia for at undersøge om det bliver rettet og i så fald hvor lang tid det tager. Disse forskere har ingen intention om at vildlede nogen, men da det er forudsigeligt at nogen måske bliver vildledt af den fejlagtige information inden den bliver rettet, så er vildledningen intentionel og dermed disinformation (Fallis 2014).
} 
stavelige mening. Groft sagt er en implikatur ${ }^{3}$ en intentionel merbetydning eller underforståethed af det ytrede, der er afhængig af konteksten for det ytrede. Det er udelukkende i relation til konteksten, at det er muligt at regne implikaturen ud.

Hvis det, der implikeres, er falsk - dvs. hvis merbetydningen eller det underforståede er falsk - er der tale om en falsk implikatur (Grice 1967). Sand disinformation er baseret på falske implikaturer (Fallis 2015) - det der ytres er bogstavelig talt sandt, men det der implikeres er falsk, hvormed ytringen bliver vildledende. Et klassisk eksempel er Joe, der er raget uklar med nogle skumle typer. Joe gemmer sig i min kælder da det ringer på døren og jeg spørges om jeg ved hvor Joe befinder sig. Hertil svarer jeg, som sandt er, at Joe ofte hænger ud på den lokale diner. Ved at svare sådan implikerer jeg, at der er en stor sandsynlighed for at Joe også befinder sig på denne diner på nuværende tidspunkt. Eftersom jeg er klar over, at Joe befinder sig i min kælder, er det vildledende at indikere, at han er på den lokale diner, om end det er sandt, at han ofte befinder sig der. Det skal hertil nævnes at implikaturer ikke almindeligvis er vildledende. Normalt vil det, der implikeres være korrekt og dermed er implikaturen ikke vildledende. Det er de falske implikaturer, der er vildledende, fordi det implikerede ikke stemmer overens med tingenes faktiske tilstand.

Vildledning kan også opstå på baggrund af udeladelser - dvs. situationer hvor afgørende og nødvendig information udelades, bevidst eller ubevidst (Fallis 2015; Mahon 2008). I sådanne situationer afskærer man sin tilhører muligheden for at danne sig et helt og samlet overblik over 'tingenes tilstand'. I min optik kan vildledning på baggrund af bevidste udeladelser også være sand disinformation. I nogle tilfælde er det muligt at have noget information, der, når det står alene, sådan set er sandt, men samtidig vildledende fordi det er taget ud af en større sammenhæng, der som oftest er mere kompleks.

Det skulle gerne være tydeligt at forståelsen af disinformation, når den bygger på litteraturen om løgn, vildledning og bedrag, er en forståelse af disinformation som 'intentionelt vildledende information'. Disinformation defineret som en form for information står i skærende kontrast til den dominerende forståelse af information i informationsfilosofien.

\section{Information}

Det dominerende informationsbegreb i informationsfilosofien er begrebet om semantisk information - dvs. information som et begreb om semantisk indhold - i den såkaldt strengt semantiske variant, hvor sandfærdighed er påkrævet (Floridi 2005a, 2005b,

\footnotetext{
${ }^{3}$ Grice (1967) lancerer to forskellige former for implikaturer: konventionel implikatur og konversationel implikatur. Når jeg bruger begrebet 'implikatur' er det udelukkende i betydningen konversationel implikatur. Konventionelle implikaturer er de implikaturer, hvor den sproglige merbetydning ligger indlejret $\mathrm{i}$ selve ytringen uafhængigt af kontekst - de har den samme merbetydning i alle situationer.
} 
2011). Et sandhedskriterium for information betyder, at kun 'velformet, meningsfuldt og sandfærdigt data' kvalificerer som værende information. Med andre ord, hvis ikke det er sandt, så er det ikke information - 'falsk information' er en selvmodsigelse (Floridi 2005a, 2005b, 2011).

Sandhedskravet til semantisk information har flere oprindelser. Én oprindelse er ideen om information som universets byggesten og et ønske om at udelukke kontradiktioner og 'falsk information' som værende information. Rationalet for udelukkelsen er, at såfremt (sandfærdig) information negeres, hvormed der opstår et indholdsmæssigt tab, så sikres det, at der også er et værdimæssigt tab - det er ikke længere information (Floridi 2005a, 2005b, 2011). Når semantisk information defineres ved sandhed og misinformation og disinformation behandles som restkategorier, så må de som sagt nødvendigvis defineres ved falskhed. Mængden af semantisk indhold (dvs. velformet, meningsfuldt data) kan således deles lige over i den del, der er sandfærdig (information) og den del, der er falsk (misinformation). Den del af misinformationen der er falsk med vilje kan så kaldes disinformation (Floridi 2005b, 2011).

En anden oprindelse af sandhedskravet til information er en forståelse af information som noget der er i verden: en objektiv entitet, der eksisterer i verden uafhængigt af agenter - dvs. fysiske signaler, tingenes tilstand, indikator-relationer - der qua deres objektive eksistens ikke kan være andet end sandfærdige (Dretske 1981, 2008). Omdrejningspunktet er et givent signals informationsmæssige indhold - dvs. hvilken information, der er tilstede i signalet - fordi det er dette informationsmæssige indhold (den semantiske struktur) af givne signaler, det informationen omhandler, der kan naturalisere intentionalitet ${ }^{4}$ (dvs. forklare hvordan noget ikke-fysisk såsom mening og bevidsthed kan udspringe af en fysisk verden), hvilket er det overordnede mål for teorien (Dretske 1981, 2008). Ethvert givent signal har flere lag af informationsmæssigt indhold. Fx vil et signal med informationen 'vandet i søen fryser' samtidig indeholde informationen at 'vandet udvider sig' qua den fysiske lov om, at vand der fryser udvider sig. På samme måde vil signalet med informationen 'dette er vand' samtidig indeholde informationen 'dette er $\mathrm{H}_{2} \mathrm{O}$ '. Menneskelige agenter kan, i modsætning til andre systemer (fx computere, algoritmer, etc.), diskriminere mellem disse forskellige informationer indeholdt $i$ et givent signal. Dvs. at mennesker kan tilskrive et givent signal indholdet og meningen 'vandet fryser' uden samtidig at tilskrive det meningen 'vandet udvider sig' til trods for, at de to informationer er uløseligt forbundet via en fysisk lov om vandmolekylers reaktioner ved frost. Kun gennem mening kan agenter forstå den givne information og dermed agere med og på den. Nogle gange sker der dog fejl, og misrepræsentation opstår:

\footnotetext{
${ }^{4}$ Intentionalitet i betydningen 'aboutness' - dvs. et givent signals indhold, det det omhandler, det signalet er signal om.
} 
"once we have meaning, once the subject has articulated a structure that is selectively sensitive to the information about the $F$-ness ${ }^{5}$ of things, instances of this structure, tokens of this type, can be triggered by signals that lack the appropriate piece of information. (...) We have a case of misrepresentation - a token of a structure with a false content. We have, in a word, meaning without truth." (Dretske 1981, 194-195).

Denne 'mening uden sandhed' er det, der, når mennesker bruger den og handler på den, kan kaldes misinformation.

Semantisk information i Dretskes (1981) forstand kan måske synes irrelevant i relation til identifikation af vildledning. Relevansen består dog i at forstå, hvor sandhedskravet til information - i de teorier der opererer med et sådant krav - stammer fra. Især fordi disse teorier om semantisk information stiller krav til misinformation (og disinformation) som værende falsk netop fordi misinformationen (og disinformationen) skal stå i modsætning til det sandfærdige informationsbegreb. Således er udsagnet "false information and mis-information are not kinds of information - any more than decoy ducks and rubber ducks are kinds of ducks." (Dretske 1981, 45) blevet den gyldne standard og den primære reference i informationsfilosofi, såvel som informationsstudier, når der argumenteres for et sandhedskrav til information - også selvom det informationsbegreb, der arbejdes med, er af væsentlig anderledes karakter (fx Floridi 2005a; Budd 2011).

\section{Misinformation}

Som sagt er (sandfærdig) semantisk information udsprunget af informationsfilosofi og erkendelsesteori som konklusion på analyser af informationsbegrebet. Misinformation og disinformation er i samme ombæring blevet defineret ved falskhed som restkategorier til den sandfærdige information. Denne opdeling mellem information som sand og misinformation og disinformation som falske udfordres af muligheden for sand disinformation (som én variant ud af mange varianter af disinformation). Det interessante er da også, at i de ganske få tilfælde hvor disinformation og misinformation står i centrum for analyser og diskussioner, der opereres med et markant anderledes informationsbegreb. Et såkaldt aletisk neutralt informationsbegreb. Dette betyder at sandhedsværdien ikke er afgørende for, hvorvidt der er tale om information; information kan være falskt såvel som sandt (jf. Fallis 2014, 2015; Fox 1983). Det er fx et aletisk neutralt informationsbegreb, der figurerer i definitionen af disinformation som 'intentionelt vildledende information' (Fallis 2014, 2015).

I det ene tilfælde, hvor misinformation står i centrum for analyser og diskussion,

\footnotetext{
5 ' $F$-ness' er et uspecificeret prædikat, der kan udskiftes med en hvilken som helst egenskab - fx tingens rødhed.
} 
er det også i relation til et aletisk neutralt informationsbegreb (Fox 1983). I en sammenlignende analyse af information og misinformation som udelukkende sproglige fænomener - dvs. indholdet i sætninger såfremt nogen hører (læser) og forstår disse sætninger - konkluderes det, at information er aletisk neutralt, hvorimod misinformation er falskt (Fox 1983). Misinformation er mere specifikt en slags information, den falske information.

Selvom der er uenighed om, hvorvidt information er defineret ved sandhed (Dretske 1981, 2008; Floridi 2005a, 2005b) eller er aletisk neutralt (Fallis 2014, 2015; Fox 1983), så synes der er være bred enighed om, at misinformation er defineret ved falskhed (Dretske 1981; Floridi 2005b; Fox 1983). Således er udsagnet "When semantic content is false, this is a case of misinformation (Fox, 1983)" (Floridi 2005b, afsnit 3.2.3) blevet en standarddefinition for misinformation. Det skal understreges at 'semantisk indhold' i denne definition af misinformation refererer til semantisk indhold i bred forstand (det være sig både sprogligt, visuelt, gennem fagter, etc.) til trods for, at oprindelsen er misinformation som et udelukkende sprogligt fænomen.

Der begynder nu at tegne sig et billede af de indbyrdes relationer mellem begreberne information og misinformation mere generelt. Information er defineret som semantisk indhold, desuagtet om det kræves at være sandfærdigt eller ej og misinformation er defineret som semantisk indhold, der er falsk. Når begrebet om disinformation tages med i ligningen, er billedet dog ikke længere så simpelt.

Disinformation defineret som 'intentionel eller forsætligt vildledende information' diskuteres i relation til misinformation defineret som 'unøjagtig og vildledende information'. Begge begreber inkluderer en definition af information som 'repræsentationelt indhold' (dvs. semantisk indhold) i bred forstand, der hverken behøver være sandt eller nøjagtigt (Fallis 2015). Således ligger der ikke et eksplicit krav om falskhed i definitionerne af misinformation og disinformation, når disinformation er udgangspunktet for analysen. Tværtimod er der som sagt plads til en sandfærdig variant af disinformation. Forskellen mellem misinformation og disinformation er, at disinformation er intentionelt eller forsætligt vildledende, hvorimod misinformation blot er resultatet af fejl (Dretske 1981; Fallis 2015; Floridi 2005b). Dette gør sig gældende uafhængigt af, hvorvidt begreberne defineres ved falskhed eller ej.

I min optik kan de samme mekanismer, der gør sig gældende i forhold til sand disinformation, også gøre sig gældende i forhold til misinformation, således at det er muligt at tale om sand misinformation som en særlig variant af misinformation (Søe 2016, 2018). Dette gælder både mekanismer i form af implikaturer og mekanismerne i form af udeladelser. Jeg skelner mellem misinformation og disinformation i form af de bagvedliggende intentioner eller mangel på samme. I stedet for blot at tale om misinformation som fejl, er det muligt at specificere og definere misinformation som ikkeintenderet vildledning, mens disinformation er intentionel eller forsætlig vildledning (Søe 2016, 2018). Sand misinformation er på denne måde de tilfælde, der kan opstå, hvis der siges, vises eller gøres noget sandfærdigt samtidig med, at der ved en fejl - dvs. ikke-intenderet - grundet uvidenhed, ignorance, el.lign. udelades vigtige oplysninger og 
detaljer. Det kan fx være hvis den, der vildleder, selv er blevet vildledt. Dertil kommer de tilfælde, hvor der siges noget sandfærdigt, der samtidig er vildledende, fordi der er en merbetydning (en formodet implikatur), som ytreren ikke selv er klar over.

Griceanske implikaturer fungerer også den anden vej rundt. Det er dermed også muligt at sige noget, der bogstavelig talt er falsk, samtidig med at man implikerer noget sandt. Dette er fx tilfældet med ironi og satire - fænomener der af Grice selv regnes med som helt almindelige implikaturer, der ikke er vildledende (Grice 1967) og dermed hverken er misinformation eller disinformation. Det er netop forholdet mellem det bogstavelig talt falske og implikerede sande, der gør, at ironi og satire virker - at det kan fortælle noget om aktuelle samfundsforhold på en sjov og elegant måde - uden at det er vildledende. I en aletisk neutral forståelse af information som repræsentationelt indhold generelt er det muligt at medregne ironi og satire som varianter af information.

\section{Vildledning og ikke-vildledning}

Som allerede nævnt er der et stort fokus på kategorierne sandt og falsk, når det kommer til automatisk identifikation af misinformation og disinformation på fx Facebook og Twitter - et fokus der også gør sig gældende i retorikken vedrørende 'Fake News' som politisk fænomen. Det skulle dog gerne være tydeligt, at et sådant fokus ikke giver de 'rigtige' svar i alle tilfælde, når sand misinformation og disinformation samt satire og ironi træder ind i billedet. Det handler altså ikke om, hvorvidt et givent tweet, Facebook-opdatering, kommentar, billede, gestus, etc. er sandt (sandfærdigt) eller falsk - det handler om, hvorvidt det er vildledende eller ikke-vildledende.

For at kunne redegøre for alle aspekter og varianter af vildledning - i særdeleshed de sandfærdige varianter af misinformation og disinformation - samt for at kunne udelukke ironi og satire som varianter af vildledning - er det nødvendigt at gå bort fra sandhedskravet til information. Hvis information defineres ved sandhed, bliver konsekvensen, at sand mis- og disinformation tæller som information, mens de andre former for mis- og disinformation ikke tæller som information. Uden et specifikt sandhedskrav til information er det muligt at medregne ironi og satire som former for information samtidig med, at alle former for mis- og disinformation tæller som vildledende information. Således kan information nu defineres som 'repræsentationelt indhold', misinformation defineres som 'ikke-intenderet unøjagtig og vildledende information' og disinformation defineres som 'intentionel eller forsætligt vildledende information'.

Det er nu muligt at sætte begreberne information, misinformation og disinformation ind i figuren over vildledning, løgn og bedrag (fig. 2.1) hvormed vi kommer frem til fig. 3.1: 


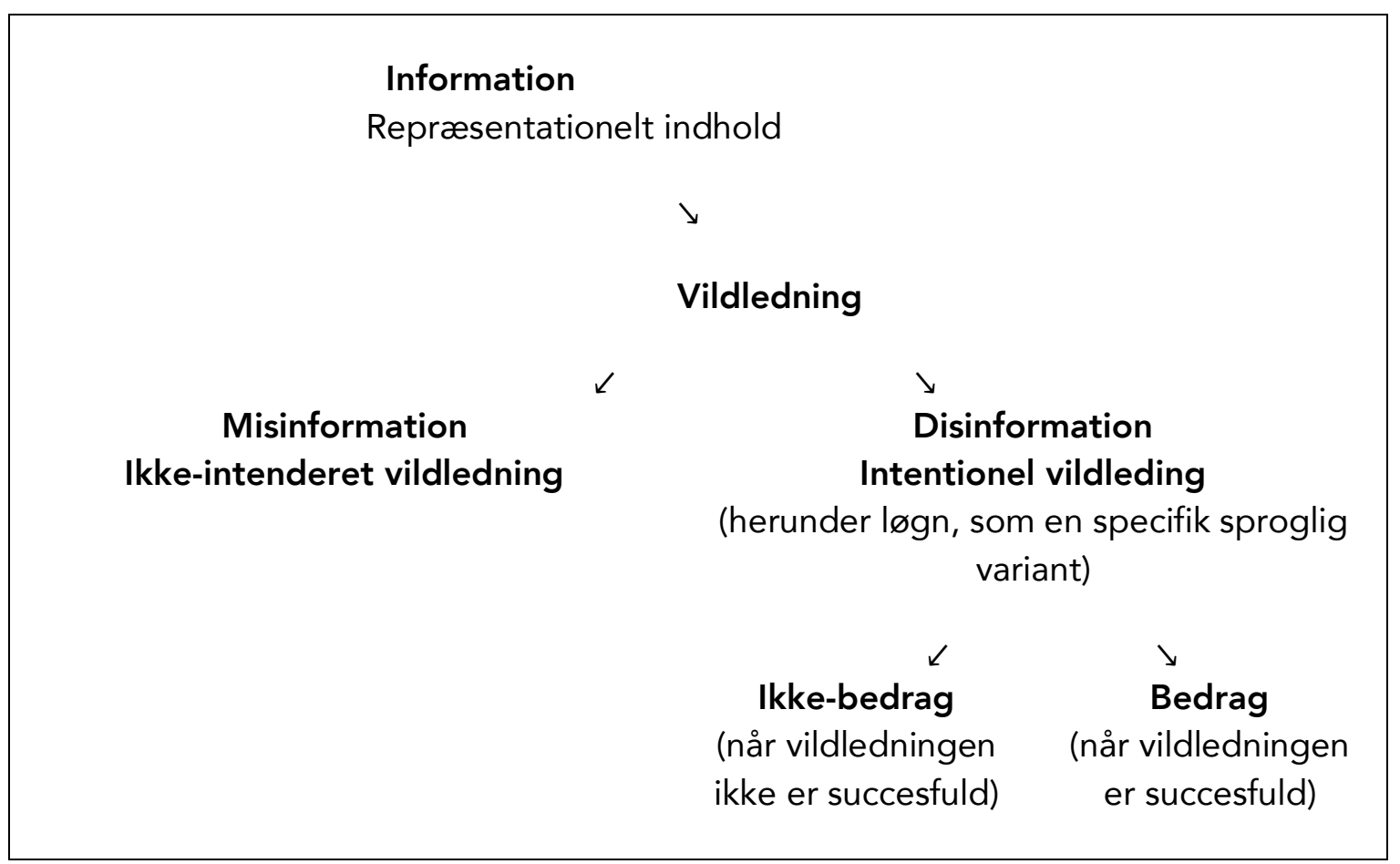

Fig. 3.1: Information og vildledning.

Således bliver vildledning en form for information, men hvor er 'ikke-vildledningen' så henne? Er den 'intentionelle ikke-vildledning' blot en restkategori, når vildledningen er udkrystalliseret af mængden af information (repræsentationelt indhold)? Hvis dette er tilfældet, bliver det igen lidt mudret, hvorledes vi kan tale om ironi og satire som 'ikkevildledning' samt at det ikke bare handler om, hvad der er sandt og hvad der er falsk. Inden for rammen af repræsentationelt indhold og som supplement til 'ikke-intenderet unøjagtig og vildledende information' (misinformation) og 'intentionel eller forsætligt vildledende information' (disinformation), vil det derfor være givtigt med en eksplicitering af 'intentionelt ikke-vildledende information' (information). Med en sådan eksplicitering bliver det endnu tydeligere, at ironi og satire er information i den 'intentionelt ikke-vildledende' forståelse og definition af begrebet.

Det er hermed muligt at tegne de indbyrdes forhold mellem information, misinformation og disinformation op som følger: 


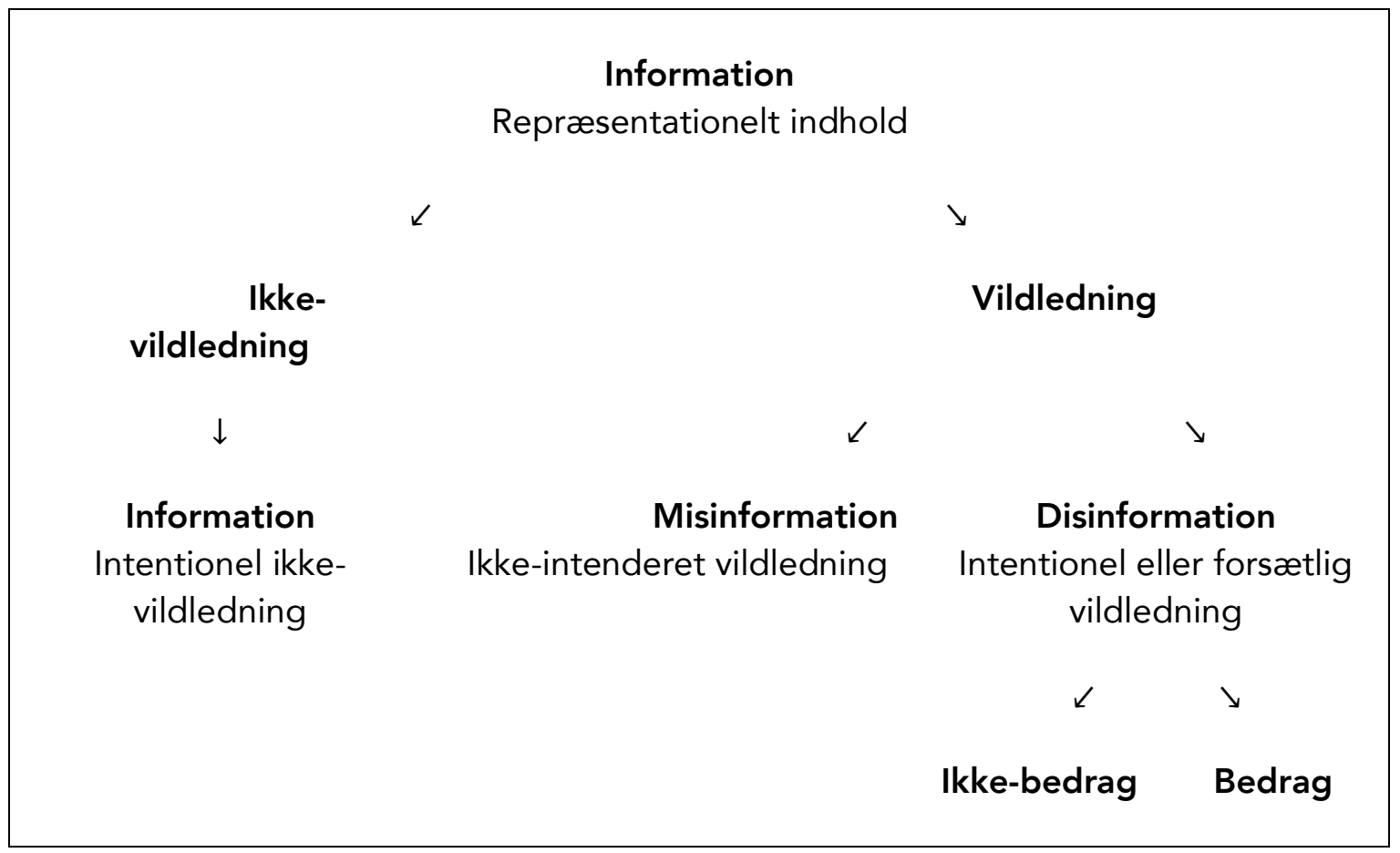

Fig. 3.2: Information, ikke-vildledning og vildledning.

Information: optræder i to forskellige aletisk neutrale forståelser, der ikke udelukker hinanden. Information kommer $\mathrm{i}$ en overordnet forståelse som repræsentationelt indhold i bred forstand $-d v s$. sproglig, visuel, handlinger, etc. - og i en specifik forståelse som intentionel ikke-vildledning. Således kan fx ironi og satire regnes med som information både generelt og specifikt.

Misinformation: er unøjagtig eller upræcis og vildledende information og dækker over al ikke-intenderet vildledning både via skrift, tale, billeder og andre handlinger. Misinformation kan ikke være bedrag, da det er en egenskab ved bedraget, at det foregår bevidst. Misinformation er dog stadig vildledning og der kan stadig være andre mennesker, der vildledes - dette har bare aldrig været intentionen. Ligesom information er misinformation aletisk neutralt, da det er muligt at tale om sand misinformation.

Disinformation: dækker over al bevidst vildledning - dvs. al intentionel eller forsætlig vildledning. Det gælder både vildledning i skrift og tale (fx løgn, sand disinformation, side-effect disinformation og adaptiv disinformation), men også den, der spredes via fx manipulerede billeder og kort, samt andre handlinger ( $\mathrm{fx}$ visuel disinformation, sideeffect disinformation og adaptiv disinformation). Al løgn er således disinformation, men det er ikke al disinformation, der er løgn. Dis- 
Løgn: er en specifik form for disinformation. Løgn er, når personer siger

information er også aletisk neutralt qua muligheden for sand disinformation. eller skriver noget, som de er overbeviste om, er falsk, samtidig med at de har en intention om, at andre skal tro, at det er sandt. Løgn er bundet til udsagn og er et sprogligt fænomen. Det er ikke et krav til løgnen, at det, der udsiges, faktisk er falsk, blot at den, der lyver, er overbevist om, at det er falsk og har en intention om, at andre skal overbevises om, at det er sandt ${ }^{6}$.

Bedrag: $\quad$ er den egenskab ved disinformation (dvs. intentionel vildledning generelt), der opstår når vildledningen virker og andre mennesker rent faktisk bliver vildledt og snydt. Det er således muligt at disinformere - eller specifikt at lyve - uden at bedrage, såfremt at der ikke er nogen, der vildledes. Hvis der derimod er nogen, der bliver vildledt, så er der tale om bedragerisk disinformation.

Da løgn er en specifik form for disinformation og bedrag er et aspekt ved vellykket disinformation er det muligt at forenkle fig. 3.2, så den udelukkende er koncentreret om begreberne information, misinformation og disinformation:

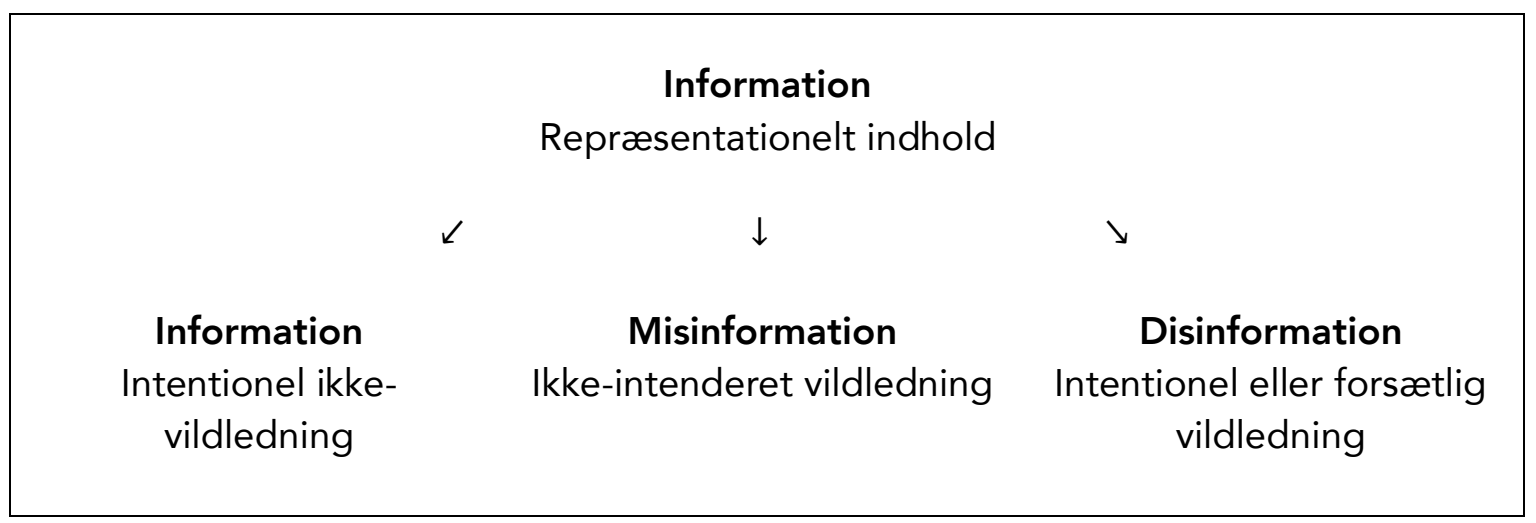

Fig. 3.3: Information, misinformation og disinformation.

\footnotetext{
${ }^{6}$ Der findes tilfælde af løgn, hvor løgneren ikke intenderer at nogen faktisk skal overbevises om at det der udsiges er sandt, såkaldte 'åbenlyse løgne' (eng. bald-faced lies) (Fallis 2011; Mahon 2008). Eksemplet er en retssag hvor et vidne åbenlyst lyver - velvidende at alle ved, at det, der siges, er løgn - med det ene formål at undgå repressalier fra den tiltalte.
} 


\section{Konklusion}

Misinformation og disinformation er komplekse begreber, der hver især kommer i mange forskellige varianter. De er dermed svære at operationalisere i forhold til fx automatisk identifikation på internettet. Det ensidige fokus på sandt vs. falsk betyder, at mange tilfælde af vildledning ikke bliver identificeret, samtidig med at former for ikkevildledning, såsom ironi og satire, falder i vildledningskategorien. Selve ideen om automatisk identifikation synes nærmest at bygge på en forståelse af information som objektiv og sandfærdig - som noget givet - og ikke på en forståelse af information som repræsentationelt indhold $\mathrm{i}$ bred forstand. Med andre ord, automatisk identifikation af misinformation og disinformation synes at bygge på en idé om, at vi kan reducere kompleksiteten til et spørgsmål om, hvad der er sandt og hvad der er falsk - at enhver historie, ethvert billede, enhver post, like, kommentar enten er direkte objektive og sandfærdige udtryk for virkeligheden eller, at de er det pure opspind.

Mine diskussioner og analyser af begreberne information, misinformation og disinformation - samt løgn, vildledning, og bedrag - viser dog, at det er væsentligt mere komplekst end som så. 'Fake News' handler ikke bare om, hvad der er løgn. Men først og fremmest er den helt centrale pointe, at det ikke er muligt at skelne mellem information som sandfærdigt og misinformation og disinformation som falskt. I stedet handler det om vildledning og ikke-vildledning og det handler om de intentioner, den forsætlighed eller utilsigtethed, der ligger bag det sagte, det viste, det gjorte. Dette er en væsentlig indsigt i forhold til en politisk debat, der i høj grad handler om hvordan misinformation og disinformation - ofte puttet ned i den fluffy og unuancerede kategori 'Fake News' - kan bekæmpes på fx de sociale medier. At skelne mellem vildledning og ikkevildledning - og i særdeleshed at skelne mellem hvornår noget er forsætligt eller utilsigtet - er ikke let, men erkendelsen af kompleksiteten er essentiel i forhold til at sikre den demokratiske debat og tilgå fænomenet. Et godt sted at starte ville være at begrave 'Fake News' begrebet og i stedet begynde at tale mere nuanceret om fænomenerne ved hjælp af de mere specifikke og komplekse begreber information, misinformation og disinformation.

\section{Litteratur}

Adler, J. (1997). Lying, Deceiving, or Falsely Implicating. Journal of Philosophy, årg. 94, s. 435-452.

Adriaans, P. (2012). Information. Stanford Encyclopedia of Philosophy. E. N. Zalta (red.), 1. udg. den 26. oktober 2012. (Fall 2013 Edition). Tilgængelig på: http://plato.stanford.edu/archives/fall2013/entries/information/ 
Budd, J.M. (2011). Meaning, truth, and information: prolegomena to a theory. Journal of Documentation, årg 67(1), s. 56-74.

Dretske, F. (1983 [1981]). Knowledge and the Flow of Information, 1. paperback udg. Cambridge: MIT Press.

Dretske, F. (2008). Epistemology and Information. I: P. Adriaans og J. van Benthem (red.). Philosophy of Information, s. 29-47. Amsterdam og Oxford: Elsevier B. V.

Fallis, D. (2010). Lying and Deception. Philosophers' Imprint, årg. 10(11)

Fallis, D. (2014). The Varieties of Disinformation. I: L. Floridi og P. Illari (red.). The Philosophy of Information Quality, s. 135-161. Cham: Springer.

Fallis, D. (2015). What is Disinformation? Library Trends, årg. 63(3) s. 401-426.

Fallis, D. (2017). Pointe fremført under paneldebat om 'Fake News' på konferencen 'DeceptiCon2017: Truth, Trust, and Tech', 21-23. August 2017, Stanford University, Palo Alto, Californien, USA.

Floridi, L. (2005a). Is Semantic Information Meaningful Data? Philosophy and Phenomological Research, årg. LXX(2), s. 351-370.

Floridi, L. (2005b). Semantic Conceptions of Information. Stanford Encyclopedia of Philosophy. E. N. Zalta (red). 1. udg. den 5. oktober 2005 (Spring 2013 Edition), Tilgængelig på: http://plato.stanford.edu/archives/spr2013/entries/informationsemantic/

Floridi, L. (2011). The Philosophy of Information. Oxford Scholarship Online.

Tilgængelig på: www.oxfordscholarship.com

Fox, C.J. (1983). Information and Misinformation. An Investigation of the Notions of Information, Misinformation, Informing, and Misinforming. Westport, CT og London: Greenwood Press.

Furner, J. (2004). Information Studies Without Information. Library Trends, årg. 52(3), S. 427-446.

Grice, P. (1967). Logic and Conversation. I: Studies in the Way of Words (1989), First Harvard University Press Paperback Edition (1991). Cambridge, MA, and London: Harvard University Pres, s. 22-40.

Hjøllund, N.-P.O. (2016). Begarets Subjekt og Informationskompetence. En reinstallering af subjektet. Ph.d.-afhandling. Det Humanistiske Fakultet, Københavns Universitet.

Kumar, K.P.K. og Geethakumari, G. (2014). Detecting misinformation in online social networks using cognitive psychology. Human-centric Computing and Information Sciences, årg. 4(1).

Mai, J.-E. (2013). The quality and qualities of information. Journal of the American Society for Information Science and Technology, årg. 64(4), s. 675-688.

Mahon, J. (2008). The Definition of Lying and Deception. Stanford Encyclopedia of Philosophy. E. N. Zalta (red). 1. udg. den 21. februar 2008 (Winter 2016 Edition), Tilgængelig på: https://plato.stanford.edu/archives/win2016/entries/lyingdefinition/

PHEME (2014). About Pheme. Tilgængelig på: www.pheme.eu [Tilgået 27.03.14] 
Robinson, L. og Bawden, D. (2014). Mind the Gab: Transitions Between Concepts of Information in Varied Domains. In F. Ibekwe-SanJuan og Dousa, T.M. (red.). Theories of Information, Communication and Knowledge, s. 121-141. Studies in History and Philosophy of Science årg. 34. Dordrecht: Springer.

Scarantino, A. og Piccinini, G. (2010). Information Without Truth. Metaphilosophy, årg. 41(3), s. 313-330.

Shao, C, Ciampaglia, GL, Flammini, A og Menczer, F. (2016). Hoaxy: A Platform for Tracking Online Misinformation. Tilgængelig på: http://dx.doi.org/10.1145/2872518.2890098

Søe, S.O. (2016). The Urge to Detect, the Need to Clarify. Gricean Perspectives on Information, Misinformation, and Disinformation, Ph.d.-afhandling. Det Humanistiske Fakultet, Københavns Universitet.

Søe, S.O. (2018). Algorithmic detection of misinformation and disinformation: Gricean Perspectives. Journal of Documentation, årg. 74(2), s. 309-332.

Wardle, C. (2016). [M|D]isinformation Reading List. First Draft News. Tilgængelig på: https://firstdraftnews.org/misinformation-reading-list/ [Tilgået 08.03.17]

Wardle, C. (2017). Fake news. It's complicated. First Draft News. Tilgængelig på: https://firstdraftnews.org/fake-news-complicated/ [Tilgået 08.03.17] 